\title{
Marketability, profitability, and profit-loss sharing: evidence from sharia banking in Indonesia
}

\author{
Ahmad Abbas \\ Department of Accounting, IAIN Parepare, Parepare, Indonesia, and \\ Ainun Arizah
Department of Accounting, \\ Ainun Arizah
Department of Accounting, \\ Universitas Muhammadiyah Makassar, Makassar, Indonesia
}

\begin{abstract}
\end{abstract}
Purpose - The purpose of this paper is to analyze marketability constructed from market share and concentration and to test its effect on the profitability and the mediation effects of profit-loss sharing under stewardship theory.

Design/methodology/approach - This research employs data of financial statements published by ten sharia commercial banks listed in the Indonesia Financial Services Authority during the period 2011-2016. The data are analyzed into path analysis model using multiple mediators.

Findings - The result reveals that sharia banks' marketability in Indonesia tends to be low. Based on the test of significance through Partial Least Square, it is found that marketability has a positive effect on the level of profitability, indicating that market share and concentration of sharia banks positively lead the change on the level of Return on Asset and Return on Equity. This paper further identifies the mediation effects emerged through mudharabah and musharakah. The results point out that mudharabah has a partial effect and musharakah has a competitive effect on the relationship between market share and profitability.

Practical implications - This paper can be a decision-maker for Central Bank and Financial Services Authority for encouraging sharia banks to enhance the power market through the mode of finances with profit-loss sharing.

Originality/value - The growth of sharia banks is currently becoming highlight of the literature of sharia banks. This paper provides insights into stewardship theory that sharia banking management provides the concept of the alignment of interest.

Keywords Profitability, Musharakah, Marketability, Mudharabah

Paper type Research paper

\section{Introduction}

Banking sectors in emerging and developing markets are characterized by the magnitude of market power (Mirzaei and Moore, 2014). Sharia banks operate under different principles compared to conventional system. Sharia banks perform on the basis of Islam principles oriented to profit-loss sharing. In countries where shariah banks operate, Central Bank provides the law to cater the regulation and supervision. In Indonesia, Bank Indonesia had launched blueprint of the development of sharia banks, describing vision, mission and the target of sharia banking since 2002. One of the future targets for 10 years is that market share of sharia banking is expected to significantly enhance financial activities nationally and internationally, about 20 percent from total banking industries. In 2008, the Law No. 21 of 2008 regarding Sharia Banking was enacted. The law came to existence for enhancing the growth in sharia banks in Indonesia. In the other words, sharia banks have enacted the

(C) Ahmad Abbas and Ainun Arizah. Published in Asian Journal of Accounting Research. Published by Emerald Publishing Limited. This article is published under the Creative Commons Attribution (CC BY 4.0) licence. Anyone may reproduce, distribute, translate and create derivative works of this article (for both commercial \& non-commercial purposes), subject to full attribution to the original publication and authors. The full terms of this licence may be seen at http://creativecommons.org/licences/by/4.0/legalcode

Received 21 August 2019 Revised 8 October 2019 Accepted 15 October 2019 
AJAR

4,2

316

sufficient law, leading the significant growth from 5 to 10 years in the future. Unfortunately, nine years after the law is enacted, the existence of sharia banks is still 5 percent. The effort to know their market power is an initial purpose in this paper. It will be analyzed through marketability.

The dominant conventional banking in the banking industry is one of factors leading sharia banks to be less powered in the banking market industry (Cupian, 2017). Market power is an effort of firms to affect the product price related to the competition, as declining competition increases market power (Weill, 2011). The existence of sharia banks becomes main highlight in the banking industry. Stagnant growth can be leading the change on the level of profitability. The empirical effort to analyze the marketability and test its effect on the profitability is an initial goal in this research.

Furthermore, the operational activities in sharia banks are based on sharia principles under Islamic doctrine. One of those is profit-loss sharing. Haron (1996) demonstrated that profit-loss sharing is a determinant of profitability in sharia banks. It is a signal to design this research. Actually, the research regarding the relationship between profit-loss sharing and profitability has been performed by Faradilla et al. (2017) and Kurniawansyah (2016). Some suggestions demonstrated by them are adding the variable or period. The suggestions are ready to be considered in this research, but something fundamental unreached by previous researcher is that they are negligent to understand the tendency of growth of finances occurred in Indonesia. Based on statistical data published by Financial Services Authority in 2017, murabahah is the dominant profit-loss sharing in sharia banks, about 60 percent, and remaining 30 percent is for mudharabah and musharakah. By understanding this phenomenon, the research about profit-loss sharing, including mudharabah and musharakah, should be related to the relationship between marketability and profitability.

This research is significant owing to two factors: first, the issue regarding the existence of sharia banks is currently becoming highlight of the literature of sharia banks and, second, some previous research studies are negligent to analyze the marketability of sharia banks.

The indirect impact of profit-loss sharing on the relationship between marketability and profitability is interesting to be tested and analyzed so that this research provides some contributions. First, this research deals with the concept of marketability built through the framework of market power theory. Second, this research also provides universal contribution given to the body of the literature on sharia finance regarding stewardship theory, providing the concept of the alignment of interest. In addition to these contributions, the result of this research can be the insight given to the practitioners of sharia banks in which market share and concentration are significant proxies to construct the marketability in a creation of profitability values.

The remainder of this research paper is organized as follows. The second section presents the literature and hypothesis development. The third and fourth sections present research method and result of the research. The last section provides summary and concluding remarks.

\section{Literature review}

\section{Market power theory, marketability and profitability}

Banking sectors in emerging and developing markets are characterized by higher market power (Mirzaei and Moore, 2014). As given by the studies of Jeon and Miller (2005) as well as Khan and Hanif (2019), there are two things that can be explained through market power theory, that is structure-conduct-performance $(\mathrm{SCP})$ and relative market power. SCP describes market concentration and market share. A firm's ability in obtaining market power is reflected from the tendency of market concentration, and market share should be identified with a purpose of controlling market. This paper calls it as marketability. 
According to the studies of Jeon and Miller (2005) as well as Khan and Hanif (2019), in describing market power implied by Berger (1995), market power can be explained through SCP describing market concentration and market share. At the point of the literature, market power theory plays a relevant role in explaining marketability. Jeon and Miller (2005) revealed that firm performance emphasizes market power of firms. It can be proxied by return of equity in which it is affected by market concentration. Market power is actually not only enhancing the profit, but leading to greater banking financial stability (Ariss, 2010).

Furthermore, the form of competition is determined by the level of market power. The competition among banks will decrease the interest rate of credit so that it reduces the probability risk of default owned by the debtor. In the business perspective, SCP is a concept of market theory assuming that market structure can affect a conduct of firm leading the growth of performance. The concentrated structure may change the conduct of competition so as to maximize the profit through the price above marginal cost $(\mathrm{P}>\mathrm{MC})$. It can occur due to the emerging market power. The bank with the dominant market share is a determinant of the strong market power.

Market power can be pushed on the basis of the effort of bank to affect the price of product and service related to the competition of market. This is called as marketability. As implied by Berger (1995), market power theory describes market concentration. It is easy for the bank with greater market power to have control on the market so that the fluctuation can be avoidable. As the result of this review, marketability in the banking industry refers to the competition of market and reflects the level of market power.

In assessing the level of competition, a variety of the measurement can be used. In the extant literature, the scholars elaborate $\mathrm{SCP}$ as a rational approach. $\mathrm{HHI}$ index is still frequently used to measure market power related to the intensity of competition. Overall, under market power theory, firms with higher power allow themselves to gain higher profit in the business.

Marketabilitiy is a firm's ability to obtain market power through the utilization of own resources in which those can be seen on the basis of commercial product and service. Sharia banks should identify their market power with a purpose to control market. This is likely to increase banking profitability. Banking sectors in emerging and developing markets are characterized by higher market power (Mirzaei and Moore, 2014).

The effect of marketability on profitability can be elaborated through market power theory that the performance is determined by the conduct of sharia banks then the conduct as determined by market structure in which sharia banks exist. Market concentration ratio is used as the size of market structure. The relationship between market power and structure is linear, and the way to identify it is by employing Hirschman-Herfindahl Index (Rettab et al., 2010). The concentrated market structure leads the change of market power. If this market power is utilized, profitability obtained by firms will be greater than their competitors. The relationship between banking concentration and profitability is reflected through Return on Asset (ROA) and Return on Equity (ROE) (Lioyd-Williams et al., 1994; Yongil and Stephen, 2006). ROA and ROE fundamentally become primary consideration for each investor to choose the stock. As stakeholders see it as the creation of financial value, ROA becomes the important measurement for the banking performance in utilizing the firm assets and ROE can become so interesting for shareholder (Rettab et al., 2010). The market concentration points out a collusive conduct and leads market power to extract the greater profit. Hence, this research assumes that the more concentrated the sharia banks, the more market power increases through $\mathrm{HHI}$ and the more leading the increase on the level of ROA and ROE, thus leading to the following hypothesis:

H1a. Market concentration has a positive effect on ROA.

$H 1 b$. Market concentration has a positive effect on ROE. 
AJAR

4,2

318

Mirzae et al. (2013) found the positive association between market share and profitability. The greater the market share, the more increased is the level of profitability. Marketability can be identified from the differentiation of product in which it leads market share. In wide market share, just for great banks with brand identification can affect price and enhance profit of banks. The empirical evidence found by Haron (1996) points out that market share is not a determinant of banking profitability. Unexpected result appears because he utilized total deposit as market share in which it is not representative measurement to assess the banking market share. Ideally, total assets reflect the proxy of market share. The greater the market share, the greater is the bank power to control product and service. The high market power is determined by market share leading the effect on the increase of banking performances (Sahile et al., 2015), and when banks compete to seize greater market share, they are not only considering the gain, but also the position in market industry. Sharia banks carrying out the differentiation of product can expand market share in the market industry so that market power obtained by them is greater. Thus, the ability of competitiveness obtained from market power is significantly needed so as to increase the financial stability (Risfandy et al., 2016), thereby leading to the following hypothesis:

H2a. Market share has a positive effect on ROA.

H2b. Market share has a positive effect on ROE.

\section{Stewardship theory and profit-loss sharing}

Stewardship theory describes the relationship between steward as a manager and principal as an owner. It provides opposite perspective on the agency theory (Davis et al., 2007). If agency theory positions manager as an agent maximizing on self-interest, stewardship theory positions him as steward in the interest of holistic organization. Ronen and Varda (2008) revealed that the role of stewardship positions managers as stewards to shareholders. Steward behavior is aligned within the interest of business principal. Alignment between manager and principal emerges because they have mutual trust with what is best for them. Cossin et al. (2015) described the characteristic of stewardship orientation based on the relation, corporate purpose and commitment to organizational goals. The basis for relation is trust, with a purpose beyond profit (intrinsic), and organizational commitment is high value. This is relevant to sharia bank. The basis for relationship between sharia banks and customers is mutual trust strengthened by religious doctrines. Sharia banks perform on the basis of Islam principles oriented to the profit and falah, the sharing in an agreed ratio, not the benchmarks of interest-based system and sharing system depending on performances (Budisantoso and Nuritomo, 2014).

Under Islamic principle, a contractual arrangement between banks as shahibul maal and customers as mudharib in a project is carried out under profit-loss sharing. Sharia banks can avoid the negative spread because they embrace flat rate. Another benefit under profit-loss sharing system is that it can enhance the stability of financial institutions. Elsa and Utami (2015) found that Islamic banking is more stable than conventional banking. PLS is actually vulnerable to agency problems, for instance Mudharib may have incentives to report less profit to shahibul maal.

Profitability is dominantly obtained from financing activities (Izhar and Asutay, 2007). Financing on profit-loss sharing affected by market power is resulting in the increase of the level of profitability. Based on the latest evidence, Bendob et al. (2017) found the effect of profit-loss sharing financing (mudharbah and musharakah) on ROE. Then, Faradilla et al. (2017) found the effect of musharakah on profitability proxied through ROA. The relationship between financing on profit-loss sharing and profitabilities is not primary key to be developed as a research hypothesis, because finances with profit-loss sharing ideally 
tend to affect sharia banking profitability and are consistently proven by scholars (Kurniawansyah, 2016; Sari and Anshori, 2016).

Mudharabah and musharakah are the products of financing using contract of profit-loss sharing. The indirect impact is forecasted to able to provide the effect of relationship between marketabilities and profitabilities. Stewardship theory will assist to elaborate mudharabah and musharakah in intervening their relation. It focuses on the situational mechanism determining principal and manager behavior. The area of thought of stewardship is based on trust that humans have duties and responsibilities for the world and religion teaches justice and truth (Cossin et al., 2015). In a nutshell, managers should not act in their own interest. They actually integrate their own with business principal and attempt to maximize firm performance. Managers act as stewards and attempt to achieve firm goals because they think that principal value is equivalent to their value.

Furthermore, profit-loss sharing ratio is fundamentally affected by market power (Ariff, 1988). Financing under profit-loss sharing would be increasing banking market value and maximizing shareholder return (Al-Deehani et al., 1999). When banks can make the differentiation of product, market share and concentration will be greater so that they are able to operate their business more efficiently, leading profitability into higher value. This principle builds trust in people that banks are fair to manage fund. Mode of financing offered by banks based on mudharabah is that banks give investment and working capital, and then customer as a steward is assigned to build a business. The profit will be shared on the basis of initial agreement, and if the loss occurs, it will be charged by banks, thus leading to the following hypothesis:

H3a. Mudharabah mediates the relationship between market concentration and ROA.

H3b. Mudharabah mediates the relationship between market concentration and ROE.

H3c. Mudharabah mediates the relationship between market share and ROA.

H3d. Mudharabah mediates the relationship between market share and ROE.

Musharakah is also referred to a mode of financing offered by banks. Customers are given flexibility to manage the fund obtained from banks. In this mode, the profit will be shared on the basis of the portion agreed by steward and principal, but in this case, if loss is obtained, both parties will charge it, thereby leading to the following hypothesis:

H4a. Musharakah mediates the relationship between market concentration and ROA.

H4b. Musharakah mediates the relationship between market concentration and ROE.

H4c. Musharakah mediates the relationship between market share and ROA.

H4d. Musharakah mediates the relationship between market share and ROE.

\section{Methodology}

\section{Sample and research variable}

The samples of this research consist of sharia commercial banks listed in Financial Services Authority. There are 13 listed banks. They should be consistently listed and provide complete data of financial statements over the period 2011-2016. Based on these criteria, three banks have been eliminated. Hence, the final sample of this research is ten sharia commercial banks listed in Financial Services Authority.

Marketability. The first variable in this research is marketability as the ability of sharia banks to obtain market power. It is identified under the tenet of market power in the perspective of SCP. SCP is attributed into market concentration proxied by $\mathrm{HHI}$ measured using comparison between the sum of the square from total revenue in individual sharia 
AJAR

4,2

320 bank and total revenue in whole sharia banks and using market share measured from total asset in individual sharia bank divided by total asset in whole sharia banks.

Profitability. The second variable is profitability constructed from ROA and ROE in percentage ratio. ROA is measured using net income divided by total assets, and ROE is calculated by dividing net income by total shareholders' equity.

Profit-loss sharing. Finances with profit-loss sharing are mediation variable consisting of mudharabah and musharakah ratio.

\section{Data analysis and test of mediation effect}

Data are analyzed into path analysis model with multiple mediators. The test of hypothesis uses bootstrapping in partial least square under significance at the 0.10 level. The effect of mediation in this research provides an indirect effect. There are two mediation effects that are possible to appear. They are full and partial mediation. Baron and Kenny (1986) implied that full mediation occurs if inclusion of the mediation variable drops the relationship between the independent variable and dependent variable. It means that no direct effect occurs in a full mediation. Then, partial mediation implies that there is not only a significant relationship between the mediator and the dependent variable, but also some direct relationship between the independent and dependent variable.

\section{Result and discussion}

\section{Descriptive statistic}

Based on Table I, the mean value of market concentration is about 0.2. It reaches zero, indicating less concentrated market. Related to market share, the mean value of sharia banks is about 0.10 , indicating that market share in sharia banks is low. Hence, less concentrated market and low share indicate that the mean of marketability in sharia bank is low.

Furthermore, the mean value of mudharabah is about 0.24 and musharakah is about 0.69. This indicates that the value of profit-loss sharing in Indonesia relies on musharakah finance, about 69 percent, compared with mudharabah, about 24 percent, only in distributing the fund. Then, profitability proxied into ROA and ROE points out the mean value of 0.53 and 4.70 . This indicates the value of ROA of 0.53 percent and ROE of 4.70 percent. It means that the bank ability in obtaining the profit for asset and equity is low, and even some firms do not gain during the period of observation.

The following average of variable based on the period of sample observation is presented in Table II. Based on Table II, the average of marketability in sharia banks identified from market share and concentration is getting decreased from year to year. The latest four years, from 2013 to 2016, have consistently witnessed a decrease, about 0.02. Furthermore, the highest average of financing variables on profit-loss sharing is obtained, about 1.08, in 2015. In the next year, the average of profit-loss sharing financing witnessed a decrease, around 0.93. This was caused by the drastic decrease of the mudharabah by 0.15 in 2016 . Related to profitability, its averagehas been decreasing from 2011 to 2016. In the latest period,

\begin{tabular}{lcrrr}
\hline Variable & Mean & Min. & Max. & SD \\
\hline Market concentration & 0.25 & 0.20 & 0.27 & 0.02 \\
Market share & 0.10 & 0.01 & 0.39 & 0.12 \\
Mudharabah & 0.24 & 0.00 & 1.43 & 0.38 \\
Musyarakah & 0.69 & 0.00 & 2.29 & 0.81 \\
Return On Asset (ROA) & 0.53 & -10.13 & 6.93 & 2.61 \\
Return On Equity (ROE) & 4.70 & -25.05 & 26.05 & 9.78 \\
\hline
\end{tabular}

Return On Asset (ROA)

0.53
Table I.

Descriptive statistic 


\begin{tabular}{|c|c|c|c|c|c|c|c|}
\hline Variables & 2011 & 2012 & 2013 & 2014 & 2015 & 2016 & $\mathrm{C}$ \\
\hline Maket concentration & 0.27 & 0.27 & 0.26 & 0.24 & 0.22 & 0.20 & \\
\hline Market share & 0.10 & 0.10 & 0.10 & 0.10 & 0.10 & 0.10 & \\
\hline Marketability & 0.37 & 0.37 & 0.36 & 0.34 & 0.32 & 0.30 & \\
\hline Mudharabah & 0.36 & 0.21 & 0.26 & 0.23 & 0.22 & 0.15 & \\
\hline Musharakah & 0.71 & 0.54 & 0.66 & 0.57 & 0.86 & 0.77 & \\
\hline Finances with profit-loss sharing & 1.07 & 0.75 & 0.92 & 0.81 & 1.08 & 0.93 & 32 \\
\hline Return On Asset (ROA) & 1.98 & 1.45 & 1.15 & 0.70 & -0.63 & -1.43 & \\
\hline Return On Equity (ROE) & 10.07 & 9.68 & 7.63 & 2.54 & 0.76 & -2.45 & Table II. \\
\hline Profitability & 12.06 & 11.13 & 8.79 & 3.24 & 0.12 & -3.89 & Average of variables \\
\hline
\end{tabular}

sharing banking profitability witnessed a decrease at the negative level, about -3.89 . It has caused the loss during the period of observation.

\section{Structural model and path analysis}

Structural model is evaluated using $R^{2}$. The result of the model is presented in Table III.

$R^{2}$ for financing variables is about 0.09 at mudharabah and 0.11 at musharakah. These results point out that 9 percent of mudhrabah and 11 percent of musharakah are affected by market share and concentration. Meanwhile, ROA has 41 percent and ROE has 59 percent. It reveals that profitability proxied through $\mathrm{ROE}$ is greater affected by marketability and finances with profit-loss sharing than ROA.

In the path analysis, the result refers to the level of significance. It is presented in Table IV. Related to path analysis with multiple mediators, it is presented in Table V.

In Table VI, mediation effects provide indirect effects. Musharakah has an opposite sign. First, direct effect has a positive effect. After musharakah mediates the relationship between marketability and profitability, the effect changes into negative. This mediation effect is

\begin{tabular}{lcc}
\hline Variable & $R^{2}$ & \\
\hline Mudharabah & 0.09 & \\
Musharakah & 0.11 & Table III. $R^{2}$ \\
ROA & 0.41 & 0.59 \\
ROE & & $R^{2}$ \\
\hline
\end{tabular}

\begin{tabular}{lccc}
\hline Model & Coefficient & $t$-statistic & $p$-value \\
\hline Market concentration $\rightarrow$ ROA & 0.29 & 3.22 & 0.00 \\
Market share $\rightarrow$ ROA & 0.20 & 1.91 & 0.05 \\
Market concentration $\rightarrow$ ROE & 0.32 & 3.24 & 0.00 \\
Market share $\rightarrow$ ROE & 0.52 & 5.34 & 0.00 \\
Market concentration $\rightarrow$ Mudharabah & 0.12 & 1.12 & 0.26 \\
Market share $\rightarrow$ Mudharabah & 0.28 & 2.15 & 0.51 \\
Market concentration $\rightarrow$ Musharakah & -0.08 & 0.65 & 0.01 \\
Market share $\rightarrow$ Musharakah & 0.31 & 2.54 & 0.00 \\
Mudharabah $\rightarrow$ ROA & 0.73 & 2.87 & 0.00 \\
Musyarakah $\rightarrow$ ROA & -0.92 & 3.87 & 0.00
\end{tabular}




\begin{tabular}{|c|c|c|c|c|}
\hline \multirow{6}{*}{$\begin{array}{l}\text { AJAR } \\
4,2\end{array}$} & \multirow{2}{*}{$\overline{\text { Model }}$} & \multirow[b]{2}{*}{ Coefficient } & \multirow[b]{2}{*}{$t$-statistic } & \multirow[b]{2}{*}{$p$-value } \\
\hline & & & & \\
\hline & Direct effect (c') & & & \\
\hline & Market concentration $\rightarrow$ ROA & 0.29 & 3.22 & 0.00 \\
\hline & Market share $\rightarrow$ ROA & 0.20 & 1.91 & 0.05 \\
\hline & Market concentration $\rightarrow \mathrm{ROE}$ & 0.32 & 3.24 & 0.00 \\
\hline \multirow{12}{*}{322} & Market share $\rightarrow$ ROE & 0.52 & 5.34 & 0.00 \\
\hline & Indirect effect $(a b)$ & & & \\
\hline & Market concentration $\rightarrow$ Mudharabah $\rightarrow$ ROA & 0.09 & 0.97 & 0.33 \\
\hline & Market concentration $\rightarrow$ Mudharabah $\rightarrow$ ROE & 0.09 & 0.92 & 0.35 \\
\hline & Market share $\rightarrow$ Mudharabah $\rightarrow$ ROA & 0.20 & 2.15 & 0.03 \\
\hline & Market share $\rightarrow$ Mudharabah $\rightarrow$ ROE & 0.21 & 1.88 & 0.06 \\
\hline & Market concentration $\rightarrow$ Musharakah $\rightarrow$ ROA & 0.07 & 0.56 & 0.57 \\
\hline & Market concentration $\rightarrow$ Musharakah $\rightarrow$ ROE & 0.07 & 0.55 & 0.58 \\
\hline & Market share $\rightarrow$ Musharakah $\rightarrow$ ROA & -0.29 & 2.52 & 0.01 \\
\hline & Market share $\rightarrow$ Musharakah $\rightarrow$ ROE & -0.27 & 2.37 & 0.01 \\
\hline & Total effect (c) & & & \\
\hline & Market concentration $\rightarrow$ ROA & 0.45 & 5.78 & 0.00 \\
\hline \multirow{3}{*}{$\begin{array}{l}\text { Table V. } \\
\text { Path analysis with } \\
\text { multiple mediators }\end{array}$} & Market share $\rightarrow$ ROA & 0.11 & 1.76 & 0.07 \\
\hline & Market concentration $\rightarrow \mathrm{ROE}$ & 0.48 & 5.77 & 0.00 \\
\hline & Market share $\rightarrow$ ROE & 0.45 & 5.53 & 0.00 \\
\hline
\end{tabular}

Table VI.

Mediation effects

\begin{tabular}{lccl}
\hline Model & Direct $(c)$ & Indirect $(a b)$ & Effect \\
\hline Market concentration $\rightarrow$ Mudharabah $\rightarrow$ ROA & $0.29^{* * *}$ & 0.09 & No \\
Market concentration $\rightarrow$ Mudharabah $\rightarrow$ ROE & $0.32^{* * *}$ & 0.09 & No \\
Market share $\rightarrow$ Mudharabah $\rightarrow$ ROA & $0.20^{* *}$ & $0.20^{* *}$ & Partial \\
Market share $\rightarrow$ Mudharabah $\rightarrow$ ROE & $0.52^{* * *}$ & $0.21^{*}$ & Partial \\
Market concentration $\rightarrow$ Musharakah $\rightarrow$ ROA & $0.29^{* * *}$ & 0.07 & No \\
Market concentration $\rightarrow$ Musharakah $\rightarrow$ ROE & $0.32^{* * *}$ & 0.07 & No \\
Market share $\rightarrow$ Musharakah $\rightarrow$ ROA & $0.20^{* *}$ & $-0.29^{* * *}$ & Competitive \\
Market share $\rightarrow$ Musharakah $\rightarrow$ ROE & $0.52^{* * *}$ & $-0.27^{* * *}$ & Competitive \\
Notes: $* 10, * * 5$ and $* * * 1$ percent & & & \\
\end{tabular}

actually called as competitive mediation. Zhao et al. (2010) revealed that competitive mediation refers to direct effect, which has an opposite direction to indirect effect. As a result of the effect of mediation, the results have partial and competitive mediation.

Related to path analysis, four main hypotheses are developed in this research. These are described into 12 sub-hypothesis presented in Table VII.

\section{Marketability and profitability}

Marketabilities in sharia banks are identified into market share and concentration. Based on the test of hypothesis in Table VII, marketabilities have a positive effect on profitability ( $H 1 a, H 1 b, H 2 a$ and $H 2 b$ accepted). Marketabilities lead the change into the level of profitability. The higher the profitability owned by sharia banks, the more efficient is the banking management in operating, hence leading the increase of ROA and ROE.

The enhanced market share and concentration tend to increase profitability through ROA and ROE. This result is consistent with the evidence of Mirzae et al. (2013) in conventional banks. Under market power, positive effect of marketability on profitability discloses that 


\begin{tabular}{|c|c|c|c|c|}
\hline Hypothesis & Predicted sign & Statistic sign & Result & Profit loss \\
\hline \multicolumn{5}{|l|}{ Marketability } \\
\hline H1a: market concentration $\rightarrow$ ROA & Positive & Positive & Accepted & \\
\hline H1b: market concentration $\rightarrow$ ROE & Positive & Positive & Accepted & \\
\hline H2a: market share $\rightarrow$ ROA & Positive & Positive & Accepted & \\
\hline$H 2 b$ : market share $\rightarrow$ ROE & Positive & Positive & Accepted & \\
\hline \multirow{5}{*}{$\begin{array}{l}\text { Mudharabah mediator } \\
\text { H3a: market concentration } \rightarrow \text { ROA } \\
\text { H3b: market concentration } \rightarrow \text { ROE } \\
\text { H3c: market share } \rightarrow \text { ROA } \\
\text { H3d: market share } \rightarrow \text { ROE }\end{array}$} & & & & \\
\hline & Mediation & Non-mediation & Rejected & \\
\hline & Mediation & Non-mediation & Rejected & \\
\hline & Mediation & Mediation & Accepted & \\
\hline & Mediation & Mediation & Accepted & \\
\hline \multicolumn{5}{|l|}{ Musharakah mediator } \\
\hline$H 4 a$ : market concentration $\rightarrow$ ROA & Mediation & Non-mediation & Rejected & \\
\hline$H 4 b$ : market concentration $\rightarrow$ ROE & Mediation & Non-mediation & Rejected & Table VII. \\
\hline$H 4 c$ : market share $\rightarrow$ ROA & Mediation & Mediation & Accepted & The result of \\
\hline H4d: market share $\rightarrow$ ROE & Mediation & Mediation & Accepted & hypotheses \\
\hline
\end{tabular}

marketability in sharia banks more concentrated in the market industry leads to the increase of market power affecting the change on the level of profitability. The higher the marketability in market industry proxied into market share and concentration, the higher is the market power. Sharia banks with higher market power can operate their business more efficiently, resulting in the increase in the level of profitability. Moreover, sharia banks making the differentiation of product can enhance their marketability so that their market power tends to be greater and leads profitability into higher level. As a result of direct effect, high market power through wider marketability is significant to increase firm performance in sharia banks. When sharia banks reach a wider market power, they can control market price and gain.

\section{Profit-loss sharing financing}

Based on Table VII concerning the test of hypothesis, the mediators of profit-loss sharing have the effects on the relationship between market share and profitability ( $H 3 c, H 3 d$ and $H 4 c, H 4 d$ accepted), but they do not have the effects on market concentration ( $H 3 a, H 3 b$ and $H 4 a, H 4 b$ rejected) because finances under mode of profit-loss sharing (mudharabah and musharakah) are not affected by market structure. Sharia banks more concentrated in market industry are not able to affect the change on the level of product and service under mode of profit-loss sharing. Hence, this result surely indicates that the measurement of market share becomes determinant of the increase in the level of profitability.

Mudharabah as a product of finance under the contract of profit-loss sharing mediates the relationship between market share and profitability. In other words, mudharabah is proven to mediate the positive effect of marketability proxied by market share on profitability proxied by ROA and ROE. Mudharabah can mediate market share to lead the change into positive direction on ROA and ROE. The indirect effect of mudharabah on profitability found in this research is consistent with prior findings (Bendob et al., 2017; Kurniawansyah, 2016). Related to the mode of mudharabah, the profit will be shared on the basis of initial agreement, and the loss will be charged by the principal (shahibul maal). Under the principle of mudharabah, people are doctrined with the trust of the conduct of sharia banks in which they are just to distribute the fund.

Musharakah can affect the relationship between market share and profitability, but it provides competitive mediation. This condition indicates that musharakah as a product of 
AJAR

4,2

324

finance has a negative effect on the relationship between marketability and profitability. The increase of market share leads the change into the level of profitability. When the relationship is mediated by musharakah, market share instead leads to the decrease in the level of profitability. Under the framework stewardship theory, banks join with customers to build business. This result deals with return rate agreed by them. The principle of musharakah charges them to take responsibilities, with loss or profit being given to them. Sharia banks in the wider market share attempt to increase the product of finances, but the likelihood of risk is high because their business are getting losses and they charge it, resulting in declining banking profitability.

\section{Conclusion}

This research is successful to analyze marketability in sharia banking industry, test its effect on profitability and find the effects mediated by mudharabah and musharakah.

Marketability is developed on the basis of market power theory identified from SCP. The declining market concentration with low market share reflects low marketability. During the period of observation, the mean value of sharia banks in market industry is less concentrated with low market share, and profitability is more declining. Based on the test of hypothesis in this research, marketability has a positive effect on profitability. It demonstrates that sharia banks in Indonesia currently have lower profiitability caused by lower marketability.

Mediators of finances on profit-loss sharing are the supplement in analyzing marketability and profitability elaborated under stewardship theory. They have indirect effects on the relationship between marketability and profitability. Through mudharabah, marketability proxied from market share leads to more increase in the level of profitability. This is called as partial mediation. Mudharabah as a product of sharia banks leads to the increase in the positive effect of market share on profitability. Meanwhile, indirect effect from musharakah has the opposite sign with direct effect called as competitive mediation. This result concludes that the utilization of musharakah leads market share to decrease the level of profitability.

The specification of analysis model is very important in this research so as to provide accurate inferences so that providing some implications. First, this research is documented to the development of the body of the literature with respect to sharia finance. Second, the evidence is provided by this research that the growth of sharia economy forced by market share and optimization of profit-loss sharing financing is its mediator. This finding can be a decision-maker for Central Bank and Financial Services Authority in which they should be encouraging the sharia financial institution to enrich a variety of products and increase services through financial technology.

Partial Least Square is a statistical tool allowing small sample. Future research should add the level of sample with a statistical tool under parameter-oriented and maximum likelihood so that the concept of marketability used in this research could be developed further. In addition, the attribute to construct marketability is only represented by market share and concentration. For completing it, further research needs to add another attribute. Finally, this research expects that 5-10 years from now, there will be a rich literature on marketability of sharia financial institution, which will encourage scholars, professional, policy maker and the business community to revisit this research paper.

\section{References}

Al-Deehani, T., Karim, R.A.A. and Murinde, V. (1999), "The capital structure of Islamic banks under the contractual obligation of profit sharing", International Journal of Theoretical and Applied Finance, Vol. 2 No. 3, pp. 243-283, available at: http://doi.org/10.1142/S0219024999000157

Ariff, M. (1988), "Islamic banking”, Asian-Pacific Economic Literature, Vol. 2 No. 2, pp. 48-64, available at: http://doi.org/https://doi.org/10.1111/j.1467-8411.1988.tb00200.x 
Ariss, R.T. (2010), "Competitive conditions in islamic and conventional banking: a global perspective", Review of Financial Economics, Vol. 19 No. 3, pp. 101-108, available at: http://doi.org/10.1016/j. rfe.2010.03.002

Baron, R. and Kenny, D.A. (1986), "Moderator-mediator variables distinction in psychological research: conceptual, strategic, and statistical considerations", Journal of Personality and Social Psychology, Vol. 51 No. 6, pp. 117-1182, available at: http://doi.org/10.1017/CBO9781107415324.004

Bendob, A., Bennaceur, F. and Benahmeddaho, R. (2017), "Does the profit and loss sharing financing increase the performance of does the profit and loss sharing financing increase the performance of Islamic banks?", Annals of the University Dunarea de Jos of Galati: Fascicle: I, Economics \& Applied Informatics, Vol. 23 No. 3, pp. 54-67.

Berger, A.N. (1995), "The profit-structure relationship in banking - tests of market-power and efficientstructure hypotheses", Journal of Money, Credit, and Banking, Vol. 27 No. 2, pp. 404-431.

Budisantoso, T. and Nuritomo (2014), Bank dan Lembaga Keuangan Lain, Edisi 3, Salemba Empat, Jakarta.

Cossin, D., Ong, B.H. and Coughlan, S. (2015), "A practical perspective: stewardship fostering responsible long-term wealth creation”, Vol. 27 No. 2, pp. 404-431, available at: www.imd.org/ globalassets/board.../stewardship_2015.pdf (accessed April 12, 2018).

Cupian, M.A. (2017), "Competitive condition and market power of Islamic banks in Indonesia", International Journal of Islamic and Middle Eastern Finance and Management, Vol. 10 No. 1, pp. 77-91, available at: http://doi.org/https://doi.org/10.1108/IMEFM-09-2015-0098

Davis, J.H., Frankforter, S., Vollrath, D. and Hill, V. (2007), "An empirical test of stewardship theory", Journal of Business and Leadership: Research, Practice, and Teaching, Vol. 3 No. 1, pp. 40-50.

Elsa and Utami, W. (2015), "Studi Komparasi Efisien, Kualitas Aset, dan Stabilitas pada Bank Umum Syariah dan Bank Umum Konvensional di Indonesia Periode 2010-2014”, Jurnal Ilmu Ekonomi dan Sosial, Vol. 4 No. 1, pp. 104-114.

Faradilla, C., Arfan, M. and Shabri, M. (2017), "Pengaruh Pembiayaan Murabahah, Istishna, Ijarah, Mudharabah Dan Musyarakah Terhadap Profitabilitas Bank Umum Syariah Di Indonesia", Jurnal Magister Akuntansi Pascasarjana Universitas Syiah Kuala, Vol. 6 No. 2, pp. 227-236, available at: http://doi.org/10.15408/ess.v6i2.3776

Haron, S. (1996), "Competition and other external determinants of the profitability of Islamic banks", Islamic Economic Studies, Vol. 4 No. 1, pp. 49-64.

Izhar and Asutay (2007), "Estimating the profitability of islamic banking: evidence from Bank Muamalat Indonesia”, Review of Islamic Economics, Vol. 11 No. 2, pp. 17-29, available at: www. emeraldinsight.com/doi/10.1108/03068290110357708

Jeon, Y. and Miller, S.M. (2005), “Bank performance: market power or efficient structure?”, Economics working papers, available at: https://opencommons.uconn.edu/econ_wpapers/200523 (accessed April 25, 2018).

Khan, M.U.H. and Hanif, M.N. (2019), “An empirical evaluation of 'structure-conduct-performance' and 'efficient-structure' paradigms inbanking sector of Pakistan”, International Review of Applied Economics, Vol. 33 No. 5, pp. 682-696, available at: http://doi.org/10.1080/02692171.2018.1518411

Kurniawansyah, D. (2016), "Profit Loss Sharing Funding dan Financing Terhadap Profitabilitas Bank Umum Syari'ah di Indonesia dengan Efisiensi dan Risiko Sebagai Mediasi”, Jurnal Akuntansi Dan Keuangan, Vol. 18 No. 1, pp. 44-58, available at: http://doi.org/10.9744/jak.18.1.44-58

Lioyd-Williams, D.M., Molyneux, P. and Thornton, J. (1994), "Market structure and performance in Spanish banking", Journal of Banking and Finance, Vol. 18, pp. 433-444.

Mirzae, A., Moore, T. and Liu, G. (2013), "Does market structure matter on banks' profitability and stability? Emerging vs. advanced economies", Journal of Banking \& Finance, Vol. 37 No. 8, pp. 2920-2937, available at: http://doi.org/10.1016/j.jbankfin.2013.04.031

Mirzaei, A. and Moore, T. (2014), "What are the driving forces of bank competition across different income groups of countries?", Journal of International Financial Markets, Institutions and Money, Vol. 32 No. 1, pp. 38-71, available at: http://doi.org/10.1016/j.intfin.2014.05.003 
AJAR

4,2

326
Rettab, B., Kashani, H., Obay, L. and Rao, A. (2010), "Impact of market power and efficiency on performance of banks in the Gulf cooperation council countries", International Research Journal of Finance and Economics, Vol. 50 No. 50, pp. 190-203.

Risfandy, T., Husa, P.P. and Asrihapsari, A. (2016), "Daya Saing Bank Syariah di Sebuah Negara Religius: Temuab Empirik di Indonesia”, Jurnal Keuangan Dan Perbankan, Vol. 20 No. 2, pp. 282-291, available at: http://jurnal.unmer.ac.id/index.php/jkdp/article/view/360

Ronen, J. and Varda, Y. (2008), Earnings Management: Emerging Insights in Theory, Practice, and Research, Springer, New York, NY.

Sahile, S.W.G., Taurus, D. and Cheruiyot, T. (2015), "Market structure-performance hypothesis in Kenyan banking industry", International Journal of Emerging Markets, Vol. 10 No. 4, pp. 697-710, available at: www.emeraldinsight.com/doi/abs/10.1108/IJoEM-12-2012-0178\%0D

Sari, D.W. and Anshori, M.Y. (2016), "Studi PadaBank Syariah Di Indonesia Periode Maret 2015 - Agustus 2016”, Accounting and Management Journal, Vol. 1 No. 1, pp. 1-8.

Weill, L. (2011), "Do Islamic banks have greater market power?”, Comparative Economic Studies, Vol. 53 No. 2, pp. 291-306, available at: http://doi.org/10.1057/ces.2011.1

Yongil, J. and Stephen, M.M. (2006), Market Definition, Concentration, and Bank Performance, University of Connecticut, Storrs, CT.

Zhao, X., Lynch, J.G. Jr, and Chen, Q. (2010), "Reconsidering Baron and Kenny: Myths and Trusts about Mediation Analysis", The Journal of Consumer Research, Vol. 37 No. 2, pp. 197-206.

\section{Further reading}

Bank Indonesia (2011), "Peraturan Bank Indonesia No. 13/1/PBI/2011 tentang Penilaian Tingkat Kesehatan Bank Umum”.

Nurwati, E., Azam Achsani, N., Hafidhuddin, D. and Nuryartono, N. (2014), "Market structure and bank performance: empirical evidence of Islamic Banking in Indonesia”, Asian Social Science, Vol. 10 No. 10, pp. 105-117, available at: http://doi.org/10.5539/ass.v10n10p105

Otoritas Jasa Keuangan (n.d.), available at: www.ojk.go.id

\section{Corresponding author}

Ahmad Abbas can be contacted at: ahmad.abbas@stainparepare.ac.id

For instructions on how to order reprints of this article, please visit our website:

www.emeraldgrouppublishing.com/licensing/reprints.htm

Or contact us for further details: permissions@emeraldinsight.com 